DOI: https://doi.org/10.15407/techned2018.04 $: \underline{084}$

\title{
COMPARATIVE ANALYSIS OF CONSTRUCTIVE TYPES OF COMBINED LINEAR PULSE ELECTROMECHANICAL CONVERTERS
}

Journal

Publisher

ISSN

Issue

Pages
Tekhnichna elektrodynamika

Institute of Electrodynamics National Academy of Science of Ukraine 1607-7970 (print), 2218-1903 (online)

No 4, 2018 (July/August)

$84-88$

\section{Authors}

\section{V.F. Bolyukh ${ }^{\star}$, A.A. Kocherga ${ }^{\star *}$, I.S. Shchukin ${ }^{\star \star *}$}

National Technical University «Kharkiv Polytechnic Institute»,

Kyrpychova st., 2, Kharkiv, 61002, Ukraine,

e-mail: vfbolyukh@gmail.com

* ORCID ID : http://orcid.org/0000-0001-9115-7828

** ORCID ID : http://orcid.org/0000-0002-0028-9532

*** ORCID ID : http://orcid.org/0000-0001-7982-8633

\section{Abstract}

A computer model of a linear pulsed electromechanical converter (LPEC) of a cylindrical configuration that describes electromagnetic and electromechanical processes with spatially-distributed parameters is developed. The analysis of constructive types of combined $\angle P E C$ designed to create mechanical impulses whose armatures are made in the form of a copper disk and/or multi-turn coil, which is connected in series or in parallel with the inductor, is analyzed. The nature of the electromechanical processes and distribution of the magnetic field in the active zone of the constructive types of combined LPEC is established. Using the efficiency criterion, which takes into account the electrical, force and field (induction of the magnetic scattering field) indicators and reliability in a relative form, it is shown that for all variants of the estimation strategy, the most effective design is the of the constructive type of 
combined LPEC design with the front and rear electrically conductive armature, and with the coil armature, which is connected in series with the inductor. References 10, figures 3, tables 2.

Key words: linear pulse electromechanical converter, constructive types, electrically conductive armature, coil armature, efficiency criterion.

Received: 05.03 .2018

Accepted: 19.03 .2018

Published:

\section{References}

1. Bolyukh V.F., Oleksenko S.V., Shchukin I.S. Comparative analysis of linear pulsed electromechanical converters of electromagnetic and induction types. Tekhnichna Elektrodynamika

No 5. Pp. 46-48. (Rus) DOI:

https://doi.org/10.15407/techned2016.05.046

2. Ivanov V.V., Paranin S.N., Nozdrin A.A. Semiautomatic installation of magnetic pulse compaction of powders. Materialovedenie. 2011. No 7. Pp. 42-45. (Rus)

3. Ivashin V.V., Penchev V.P. Features of the dynamics of work and energy diagrams of pulsed electromagnetic drive with parallel and series connection of excitation windings. Elektrotekhnika . 2013. No 6. Pp. 42-46. (Rus)

4. Kondratenko I.P., Zhiltsov A.V., Pashchin M.O., Vasyuk V.V. Choice of parameters of an electromechanical converter of an induction type for electrodynamic treatment of welded joints. Tekhnichna Elektrodynamika . 2017. No 5. Pp. 83-88. (Ukr) DOI:

https://doi.org/10.15407/techned2017.05.083

5. Lobanov L.M., Kondratenko I.P., Zhiltsov A.V., Karlov O.M., Pashchin M.O., Vasyuk V.V. 
Non-stationary electrophysical processes in systems of reduction of residual stresses of welded joints. Tekhnichna Elektrodynamika. 2016. No 6. Pp. 10-19. (Ukr) DOI: https://doi.org/10.154 07/techned2016.06.010

6. Tomaszewski D.N., Koshkin A.N. Modelling of linear impulse motors. Elektrotekhnika. 2006. No 1. Pp. 24-27. (Rus)

7. Comsol Multiphysics modeling and simulation software. URL: http://www.comsol.com/ .

8. Bissal A., Magnusson J., Engdahl G. Comparison of two ultra-fast actuator concept. IEEE Transactions on Magnetics

. 2012. Vol. 48. No 11. Pp. 3315-3318. DOI:

https://doi.org/10.1109/TMAG.2012.2198447

9. Bolyukh V.F., Luchuk V.F., Rassokha M.A., Shchukin I.S. High-efficiency impact electromechanical converter. Russian Electrical Engineering. 2011. Vol. 82. No 2. Pp. 104-110. DOI:

https://doi.org/10.3103/S106

8371211020027

10. Bach J., Bricquet C. Electric switching device with ultra-fast actuating mechanism and hybrid switch comprising one such device. Assignee: Schneider Electric Industries SAS. Patent US No 8686814, 2014.

$\underline{\text { PDF }}$ 